$\xi=-$

\title{
Community liquid waste management system in Gili air tourism area and its management strategy based on a SWOT analysis
}

\author{
Rosalina Edy Swandayani $^{1}{ }^{*}$, Meilinda Pahriana Sulastri $^{1}$ \\ ${ }^{1}$ Department of Biology, Faculty of Mathematic and Natural Science, Al-Azhar Islamic University, Mataram 83237, Indonesia \\ *Corresponding author E-mail: rosalinaedy50@gmail.com
}

\begin{abstract}
Lombok island is one of the international tourism destinations because of its topography and natural beauty which has its own charm for both domestic and foreign tourists. One of the famous marine tourism destinations on the island of Lombok is Gili Air. Most of the waste problems in Gili Air are domestic liquid waste, both from community waste and tourism business waste. This study is a descriptive exploratory study by exploring and describing the liquid waste management system by the community, hotel managers and restaurants in the tourism area of Gili Air. The observations were made in residential areas, hotels and restaurants on Gili Air. The determination of sampling areas and resource persons is determined by purposive sampling. Data were collected by conducting a survey at the research location through direct observation and interviews with informants. SWOT analysis were used to determine a liquid waste management strategy in Gili Air. Based on the study conducted in Gili Air, which includes residential areas, hotels and restaurants, the liquid waste management system is carried out individually using a septic-tank, land use management for wastewater with a septic tank placed at the side / back of the house and a waste management strategy can be implemented by establishing a communal and environmentally friendly waste management facility in the form of a Waste Final Disposal Plant (IPAL) for liquid waste.
\end{abstract}

Keywords: Liquid Waste; Tourism; SWOT Analysis.

\section{Introduction}

Lombok is one of the islands in West Nusa Tenggara (NTB) which has an area of approximately 473,780 hectares. This island is one of the international tourism destinations because of its topography and natural beauty which has its own charm for both domestic and foreign tourists. The tourism sector in Lombok from year to year has increased both inland tourism and marine tourism. One of the famous marine tourism destinations on the island of Lombok is Gili Air (Winner in Figures 2017).

Along with the increase of tourist visits in the Gili Air area, development has also increased as a means of supporting tourism needs. Tourism is an industry whose survival is largely determined by the merits of the environment (Soemarwoto, 2001). This industry is very sensitive to environmental damage, for example, contamination of raw water sources by domestic liquid waste.

Liquid waste is the residual waste resulting from a process that is no longer used, whether in the form of industrial, household, livestock, agricultural, and so on. The main component of liquid waste is water (99\%) while the other components are solid materials that depend on the origin of the waste (Rustama et. al, 1998) in Fitria (2010).

Most of the waste problems in Gili Air are domestic liquid waste, both from community waste and tourism business waste. Based on the survey results, most of the community, hotels, and restaurants have a septic tank to accommodate their liquid waste, but not all septic tanks accommodate liquid waste because some people only have one septic tank for the toilet. As for liquid waste from washing and bathing, it is disposed of directly into the environment. Apart from that, another problem is that the distance and size between the septic tanks are not in accordance with the distance standards that have been determined based on SNI 03-2398-2002.

Based on the problems that arise above, it is necessary to have appropriate countermeasures and strategies to manage waste. This aims to make the prevention efforts more effective and efficient because it uses a more systematic management to overcome liquid waste in the tourism area of Gili Air.

\section{Method}

This study is a descriptive exploratory study by exploring and describing the liquid waste management system by the community, hotel managers and restaurants in the tourism area of Gili Air. 


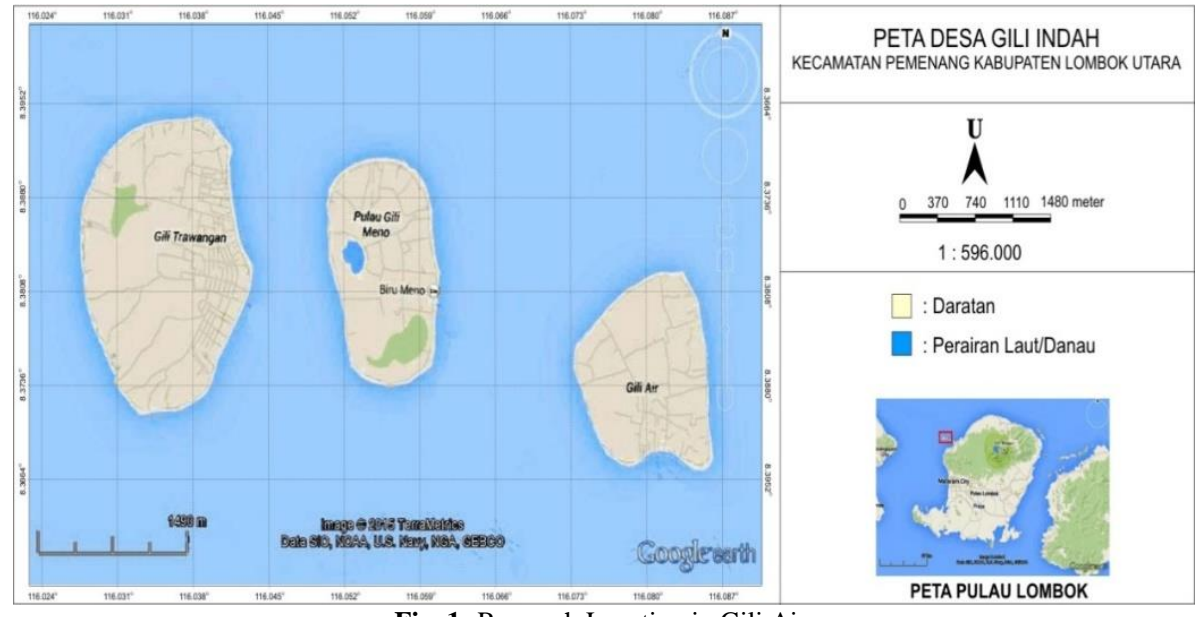

Fig. 1: Research Location in Gili Air.

Field observations were made to obtain an overview of the domestic waste management system, which begins with determining the sampling area and resource persons. The observations were made in residential areas, hotels and restaurants on Gili Air. The determination of sampling areas and resource persons is determined by purposive sampling (Tongco, 2007; Hakim, 2014). Data were collected by conducting a survey at the research location through direct observation and interviews with informants. Resource persons consist of village and community officials as well as hotel and restaurant managers who are carried out accidentally.

\subsection{SWOT analysis}

It is a method used to determine a liquid waste management strategy including strengths, opportunities, weaknesses, and threats to conditions in Gili Air.

\section{Results and discussion}

\subsection{Liquid waste management system in Gili air}

Based on a survey conducted in Gili Air, which includes residential areas, hotels and restaurants, it was found that liquid waste management is still carried out individually and there is no communal management system. This is because there is no third party that manages it so that it is managed by the community or business owners themselves. The liquid waste in residential areas is generally disposed of into a septic tank as well as in hotels and restaurants.

Communities in residential areas in Gili Air generally have more than one septic tank separated from human waste and liquid waste from washing. In addition, the size of the septic tank that was made was bigger so that it was never drained. Based on the information from the community, several times the septic tank in their house was almost full, giving off an unpleasant smell. People usually put lye into septic tanks to reduce odors and clogging.

Natrium hydroxide $(\mathrm{NaOH})$ is the chemical element of lye. The lye has destructive properties or damages objects in its path including garbage, sanitary napkins or other objects that clog the drainpipe. However, its use has a negative impact on the environment because in the septic tank there are microorganisms that help break down organic waste. In addition, other impacts will be absorbed into the soil and will disrupt the balance of the ecosystem in the area (Widyastuti, 2005)

The liquid waste in the hotel and restaurant area in Gili Air is generally managed privately by the business owner. The waste is managed with septic tanks of various sizes. Each hotel room generally has its own septic tank which is then collected in a larger septic tank (Figure 2). Hotel and restaurant managers generally carry out periodic checks on the septic tanks at the place of business. Based on interviews with hotel and restaurant managers, desludging is usually carried out once a year to once a month, after which the desludging waste is dumped in the land behind the hotel. The results of the interviews indicated that blockages often occur in this area, especially during high season. This is due to the increasing number of guests staying at the hotel, which results in more waste. An example of a septic tank in hotel and residential areas is presented in Figure 2.
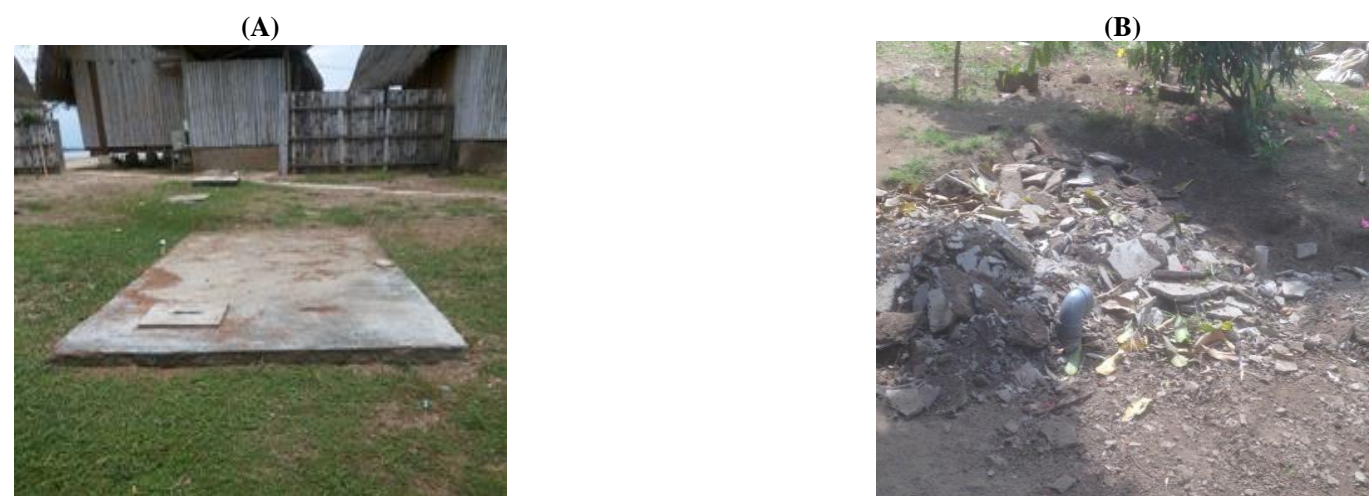

Fig. 2: An Example of A Septic Tank. Remarks: A. Septic Tank in the Hotel Area; B. Septic Tanks in Residential Areas. 
Based on the research that has been done, the size of the septic tanks in residential areas, hotels and restaurants have different sizes. This is because the number of users in each place also varies. Based on SNI-03-2398-1991, there are standard standards in the manufacture of septic tanks which include standards for the number of users, standard sizes and volume standards. However, there are several buildings on Gili Air whose size and distance between the septic tank and the well are not suitable. The SNI-03-2398-1991 as a standard in the manufacture of septic tanks is as follows:

Table 1: Requirements for Septic Tanks According to SNI-03-2398-1991

\begin{tabular}{|c|c|c|c|c|c|c|c|c|c|c|c|c|c|}
\hline \multirow{2}{*}{$\begin{array}{l}\mathrm{N} \\
\mathrm{o}\end{array}$} & \multirow{2}{*}{$\begin{array}{l}\text { Number of Users } \\
\text { (Soul) }\end{array}$} & \multicolumn{2}{|c|}{$\begin{array}{l}\text { Mud Space Require- } \\
\text { ment (m2) }\end{array}$} & \multirow{2}{*}{$\begin{array}{l}\text { Wet Room Require- } \\
\text { ment }(\mathrm{m} 2)\end{array}$} & \multirow{2}{*}{$\begin{array}{l}\text { Water Free } \\
\text { Space }(\mathrm{m} 2)\end{array}$} & \multicolumn{2}{|c|}{$\begin{array}{l}\text { Total Volume } \\
\text { (m3) }\end{array}$} & \multicolumn{3}{|c|}{$\begin{array}{l}\text { Size }(\mathrm{m}) \\
2 \text { years }\end{array}$} & \multicolumn{3}{|c|}{3 years } \\
\hline & & 2 years & 3 years & & & $\begin{array}{l}2 \\
\text { years }\end{array}$ & $\begin{array}{l}3 \\
\text { years }\end{array}$ & $\mathrm{P}$ & $\mathrm{L}$ & $\mathrm{T}$ & $\mathrm{P}$ & $\mathrm{L}$ & $\mathrm{T}$ \\
\hline 1 & 5 & 0.4 & 0.6 & 1.0 & 0.3 & 1.7 & 1.9 & $\begin{array}{l}1 . \\
6\end{array}$ & $\begin{array}{l}0 . \\
8\end{array}$ & $\begin{array}{l}1 . \\
3\end{array}$ & $\begin{array}{l}1 . \\
7\end{array}$ & $\begin{array}{l}0 . \\
9\end{array}$ & $\begin{array}{l}1 . \\
3\end{array}$ \\
\hline 2 & 10 & 0.8 & 1.2 & 2.0 & 0.5 & 3.3 & 3.7 & $\begin{array}{l}2 . \\
2\end{array}$ & 1. & 4. & $\begin{array}{l}2 . \\
3\end{array}$ & $\begin{array}{l}1 . \\
2\end{array}$ & $\begin{array}{l}1 . \\
4\end{array}$ \\
\hline 3 & 15 & 1.2 & 1.8 & 3.0 & 0.8 & 5.0 & 5.6 & $\begin{array}{l}2 . \\
6\end{array}$ & 1. & $\begin{array}{l}1 . \\
5\end{array}$ & $\begin{array}{l}2 . \\
8\end{array}$ & $\begin{array}{l}1 . \\
4\end{array}$ & $\begin{array}{l}1 . \\
5\end{array}$ \\
\hline 4 & 20 & 1.6 & 2.4 & 4.0 & 1.0 & 6.6 & 7.4 & $\begin{array}{l}3 . \\
0\end{array}$ & $\begin{array}{l}1 . \\
5\end{array}$ & $\begin{array}{l}1 . \\
5\end{array}$ & $\begin{array}{l}3 . \\
2\end{array}$ & $\begin{array}{l}1 . \\
6\end{array}$ & $\begin{array}{l}1 . \\
5\end{array}$ \\
\hline 5 & 25 & 2.0 & 3.0 & 5.0 & 1.3 & 8.3 & 9.3 & $\begin{array}{l}3 . \\
3\end{array}$ & $\begin{array}{l}1 . \\
6\end{array}$ & $\begin{array}{l}1 . \\
6\end{array}$ & $\begin{array}{l}3 . \\
4\end{array}$ & $\begin{array}{l}1 . \\
7\end{array}$ & $\begin{array}{l}1 . \\
6\end{array}$ \\
\hline
\end{tabular}

Based on the table above, the standard requirements for making septic tanks according to SNI are determined. As for the reality in the field, the community generally makes large septic tanks so that it is rarely desludged (Table 2). In addition, the bottom of the septic tank in the area is usually directly attached to the ground so that it is absorbed more quickly. However, this has a negative impact on the environment because it is directly absorbed by the soil, making it difficult to neutralize it. The distance of the septic tank based on SNI - 03-2398-2001 is presented in Table 3.

Table 2: Average Septick-Tank in Settlement Areas

\begin{tabular}{|c|c|c|c|c|c|c|}
\hline No & Number of Users (Soul) & $\begin{array}{l}\text { Size (m) } \\
\mathrm{P}\end{array}$ & $\mathrm{L}$ & $\mathrm{T}$ & Volume (m3) & Suction Period \\
\hline 1 & 2 & 2.0 & 1.5 & 1.8 & 5.3 & 0 \\
\hline 2 & 3 & 2.1 & 1.5 & 2.0 & 6.4 & 0 \\
\hline 3 & 4 & 2.1 & 1.6 & 2.2 & 7.0 & 0 \\
\hline 4 & 5 & 2.3 & 1.8 & 2.3 & 8.9 & 0 \\
\hline 5 & 6 & 2.3 & 2.0 & 2.3 & 10.1 & 0 \\
\hline 6 & 7 & 2.5 & 2.0 & 2.5 & 12.5 & 0 \\
\hline 7 & 8 & 2.5 & 2.0 & 3.0 & 15.0 & 0 \\
\hline
\end{tabular}

Table 3: Septic Tank Distance Based on SNI - 03-2398-2001

\begin{tabular}{llll}
\hline No & Distance From & Septic-Tank & Infiltration Field \\
\hline 1 & Building & $1.5 \mathrm{~m}$ & $1.5 \mathrm{~m}$ \\
2 & Well & $10 \mathrm{~m}$ & $10 \mathrm{~m}$ \\
3 & Water pipe & $3 \mathrm{~m}$ & $3 \mathrm{~m}$ \\
\hline
\end{tabular}

Based on the table above, the standard distance between the septic tank and other buildings is based on SNI-03-2398-2001. Based on the survey in the field, the distance between the septic tank and the well was some that were not up to standard (Table 4). This is due to the limited knowledge of the community about the standard distance for making these septic tanks. In addition, some house yards and hotel yards have narrow land so that the distance between the septic tank and the well is not up to standard.

Table 4: Distance of Wells to Septic Tanks in Residential Areas

\begin{tabular}{lll}
\hline No & Well distance to Septic-Tank $(\mathrm{m})$ & amount \\
\hline 1 & 4 & 6 \\
2 & 5 & 1 \\
3 & 7 & 7 \\
4 & 10 & 9 \\
5 & 12 & 1 \\
6 & 13 & 4 \\
7 & 15 & 2 \\
Total & & 30 \\
\hline
\end{tabular}

Based on the table above, of the 30 respondents, there are 14 respondents who have a distance between the well and the septic tank that is not in accordance with the SNI - 03-2398-2001 standard, which is a minimum of $10 \mathrm{~m}$. This is very dangerous because well water can be contaminated.

\subsection{Land use management as a place for liquid waste management in Gili Air}

Based on interviews with sources, it was found that the liquid waste management system in the area was identified. As for the community and business owners generally have liquid waste management in the form of a septic tank located in the yard of the house or the yard of the hotel and restaurant. The survey results indicated that the septic tank was located on the side or back of the building. This is because generally the bathroom is located at the back so that the waste disposal is arranged so that it is close to the source of the waste. In addition, if there is a problem in the form of a full septic tank or blockage, it will not disturb the aesthetics of the area. Meanwhile, the well is placed in the back and the place is far from the building and disposal area so that it is not contaminated from hazardous substances from liquid waste. 
Based on the research that has been conducted, the construction of septic tanks by residents in Gili Air was found that some were not in accordance with SNI - 03-2398-2001. In addition, several houses also had wells that were too close to the septic tank. Based on SNI - 032398-2001, the minimum distance between the well and the septic tank is $10 \mathrm{~m}$, however, based on the survey results, there are residents' houses with a distance between the wells and the septic tank which is less than $10 \mathrm{~m}$. This can increase the possibility of contamination of substances from the septic tank to the well. These substances are very dangerous and can pollute the environment around them.

According to Sudarmadji (2013), septic tanks are considered the best way to treat wastewater, even though in fact, soil and water pollution still occurs through seepage. Distance requirements in rural areas are easier to meet because of the lower occupancy density. Septic tanks are not suitable for use in densely populated cities. Even for a very simple house with a narrow yard, it is impossible to build a proper septic tank in every house. However, if one septic tank is made for several houses, it is difficult to manage.
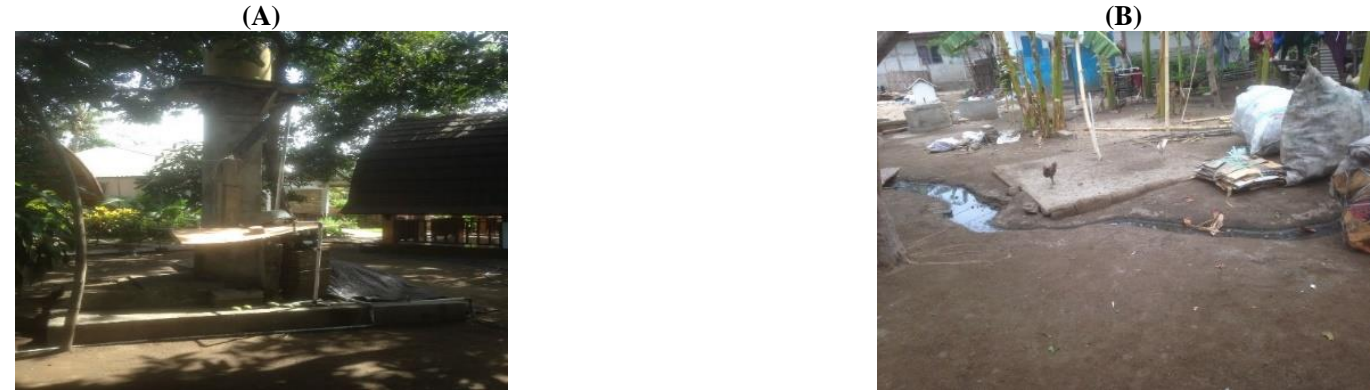

Fig. 3: Layout of Septic Tanks and Wells in Residential Areas. Notes: A. Well in People's Houses., B. Septic Tank in People's Houses.

Based on the picture above, it is known the layout of the wells and septic tanks on the home page. Almost all people in Gili Air have a well in their yard. One well is used by several neighbouring households. Well water on Gili Air is generally used for washing, bathing, and watering plants and not for drinking and cooking water. This is because the well water tastes a little salty. People in Gili Air generally use PDAM as clean water.

Waste Management System Strategy

The strategy of the domestic waste management system in Gili Air is presented in Table 5.

Table 5: Sewage Management System Strategy Strength / S

Internal

Eksternal
- Gili Air is a national and international destination

- The type of soil on Gili Air is in the form of porous soil so that it is able to absorb fluids well.

- There is a place to manage liquid waste in the form of a septic tank in every house and business place in the Gili Air area

\section{Weakness / W}

- $\quad$ There are no communal domestic waste management sites on Gili Air

- Not all houses have a septic tank for liquid waste management with SNI standards.

- The distance between the septic tank and the well and many buildings is not in accordance with SNI.

- Desludging of the septic tank in residential areas is generally never carried out and if it is full, lye is given to the septic tank.

- Liquid waste in the form of liquid originating from the kitchen and laundry is usually dumped in the yard.

\section{Opportunity / O}

- Communal and environmentally friendly domestic waste management in Gili Air

- Challenge / T

- Community knowledge in Gili Air regarding liquid waste management is still lacking.

- $\quad$ There is no organization that deals with problems related to liquid waste in Gili Air

- $\quad$ The community and village apartments do not want to build a waste management site on Gili Air for fear of disrupting tourism activities.

- There is concern that the increasing number of tourists will become an over carrying capacity, which will disrupt the sustainability of Gili Air
}

\section{Strategy S / O}

- The creation of a final waste disposal plant (IPAL) in the Gili Air area

- $\quad$ Strategy S / T

- $\quad$ Provide guidance to the community regarding liquid waste management.

- Establishment of an organization that handles liquid waste problems.

- $\quad$ Socialization to increase public knowledge about the importance of waste treatment.

- Develop an environmental carrying capacity assessment framework in the Gili Air area to determine the maximum number of visitors.
Strategy W/O

- $\quad$ The creation of an environmentally friendly liquid waste management facility in Gili Air

- $\quad$ Strategy W / T

- Increasing cooperation between various parties in planning and managing the environment in Gili Air.

- Increase socialization to the community about the importance of proper domestic waste management.

Based on Table 6 the SWOT matrix, the liquid waste management strategy in Gili Air is as follows:

- Establishment of a communal and environmentally friendly waste management facility in the form of a Waste Final Disposal Facility (IPAL) for liquid waste.

- Increase knowledge of the public and business owners in the form of guidance related to proper domestic waste management. This can be done in collaboration with various competent stakeholders such as local governments, related agencies, academics, and NGOs.

- Forming an organization or institution in Gili Air to deal with liquid waste problems. 
- Develop an assessment framework for the carrying capacity of the environment in the Gili Air area to determine the maximum number of visitors so that the amount of liquid waste produced can be controlled.

\section{Conclusion}

1) The liquid waste management system is carried out individually using a septic-tank.

2) Land use management for wastewater with a septic tank placed at the side / back of the house.

3) A waste management strategy can be implemented by establishing a communal and environmentally friendly waste management facility in the form of a Waste Final Disposal Plant (IPAL) for liquid waste.

\section{References}

[1] Hakim, L. 2014. Etnobotani dan Manajemen Kebun-Pekarangan Rumah: Ketahanan Pangan, Kesehatan dan Agrowisata. Selaras. Malangw.

[2] Paranna, Karunia. 2013. Analisis Aspek Akuntasi dan CSR Atas Pengolahan Sampah di Kota Kendari. Skripsi: UNHAS Makasar.

[3] Permadi, E., W. 2012. Pelaksanaan Sales Promotion Hotel Permata Krakatautentang Kepuasan Menginap Tamu. Repository: UPI.

[4] Kecamatan Pemenang Dalam Angka Tahun 2017.

[5] Soemarwoto, Otto. 2011. Ekologi, Lingkungan Hidup dan Pembangunan. Repository. UGM.

[6] Widyastuti, I., Anas, T., Muluk. 2005. Pemanfaatan Limbah Pengolahan Ikan Sebagai Bahan Pupuk Organik. Penilitian Hibah Bersaing X. Repository USU. 